\title{
Acknowledgements and Dedication
}

An acknowledgement in a monograph is a rare opportunity for an academic to be self-indulgent and sentimental. In the main, good academic work is characterised by the single-minded, dispassionate pursuit of truth and knowledge. In that pursuit one must keep one's feelings to oneself and kill one's darlings. But self-indulgence is not all bad and often sentimentality is uniquely appropriate when giving thanks and acknowledging one's debt.

In writing this book I have incurred debts of varying sizes to a large number of people. These debts go back a long way.

I would like to begin by thanking my parents Ged and Dawn Shields, who have supported me in every possible way. The thought that this achievement would make them proud was a constant source of strength.

I have been fortunate to have been a member of groups of political theorists and political philosophers at several institutions. I would like to thank the Philosophy and Politics departments at Keele University and the Politics department at the University of York for making the study of political philosophy seem irresistible to me. Thanks is owed to Glen Newey, Paul Bou-Habib, Monica Mookherjee, Mat Matravers, Tim Stanton, Jon Parkin and David Edwards. I would especially like to thank John Horton at Keele who encouraged me to study the subject further and nurtured my interest in sufficientarianism when supervising my undergraduate dissertation.

My main academic debt is to Andrew Williams, who supervised my $\mathrm{PhD}$ thesis, on which some of the chapters are based. His penetrating criticisms, detailed comments and helpful suggestions have made me the political theorist I am today and have greatly 
improved the argument within the book. I owe a significant debt to Fabienne Peter, who became my supervisor at a time when I was struggling to clarify my thoughts. Under her close supervision I quickly overcame my difficulties. Without her input, in particular on the chapter on autonomy, this book would certainly have been much worse.

I would also like to thank two anonymous reviewers at Utilitas for two rounds of detailed comments on a paper based on the arguments of Chapter 1 . These comments have greatly improved my understanding of sufficientarianism and the arguments contained in this book.

A large number of people at the University of Warwick have helped me whilst writing the thesis. For their help and encouragement I would like to thank Enrique Camacho, Stephen Butterfill, Kai Spiekermann, Stephen Houlgate, Eileen John, Alex Sutton, Keith Wilson and Chris Godfree-Morrell. Special thanks should go to those with whom I have had extensive discussions about all or part of the thesis. These include Matthew Clayton, Ed Page, Chris Clarke, Douglas Bamford, Victor Tadros and all members of the Centre for Ethics Law and Public Affairs, University of Warwick. I have benefitted enormously from several conversations in various public houses and curry houses with Tim Fowler, Adam Slavny, Dean Machin and Brian McElwee. Furthermore, the examiners of my PhD, Adam Swift and Zofia Stemplowska, gave me invaluable comments both in my viva voce examination and in the aftermath.

In the academic year 2013/14 I took up a one-year postdoctoral research position at the McCoy Family Center for Ethics in Society at Stanford University. Not only did this provide a glorious physical environment in which to research, but the Center's weekly workshop was an excellent forum for discussion of work in progress. I am extremely grateful to Lily Lamboy, Chris Lewis, Ben Miller, Sara Mrsny, Erin Cooper, Debra Satz, Eamonn Callan, Rob Reich, Brent Sockness, Anne Newman, Kristi Olsen, Jorah Dannenberg, Allison McQueen, Tamar Schapiro, Brian Berkey, Will Braynen, Mark Budolfson, Hyunseop Kim, Julie Rose, Patrick Taylor-Smith and Alex Levitov for helping me with aspects of this book through conversation and written comments. 
I am especially grateful to Alex Levitov and Patrick Taylor-Smith for their help with the chapter on global justice.

Since January 2012, I have been a member of staff in the Manchester Centre for Political Theory (MANCEPT). I think this must be one of the best places anywhere in the world to be a political theorist and I am grateful to all of my co-members for their help with my research. I would especially like to thank Miriam Ronzoni, Christian Schemmel, Stephanie Collins, Stephen Hood, Nici Mulkeen, Joe Horton, Steve de Wijze, Richard Child, Hillel Steiner, James Pattison, Chris Mills, Dean Redfearn, Jon Quong and Tom Porter-Sinclair.

I have also collected a number of debts outside any institutional affiliation I have held. I am grateful to David Axelsen, Lasse Nielsen, Robert Huseby, Luara Ferracioli, Iwao Hirose, Sarah Hannan, Thomas Rafferty, Emily McTernan and Martin O’Neill for discussions of sufficientarianism and related matters. I am especially grateful to Paula Casal, not only for writing the paper 'Why sufficiency is not enough', which has influenced me greatly, but also for helping me along the way anonymously, as well as Philipp Kanschik and Rudolf Schüßler for inviting me to the University of Bayreuth to present at a conference on sufficientarianism where I learned a great deal from audiences and presenters.

Finally, I dedicate this book to my wife Claire Shields. Marrying her was the best thing I ever did. 